\title{
Evolution of Corn Transpiration and Leaf Water Potential During Sprinkler Irrigation
}

\author{
A. Martínez-Cob ${ }^{*}, 1$, J. Fernández-Navajas², V. Durán², J. Cavero ${ }^{1}$ \\ ${ }^{1}$ Estación Experimental de Aula Dei (CSIC), Apdo. 13034, 50080 Zaragoza, Spain. E- \\ mail: macoan@eead.csic.es \\ 2 Centro Politécnico Superior, Universidad de Zaragoza, María de Luna 1, 50018 \\ Zaragoza, Spain.
}

\begin{abstract}
Corn (Zea mays L.) transpiration during daytime solid-set sprinkler irrigation was analyzed on two neighbouring subplots to determine the effect of the transpiration reduction on water application efficiency. During each irrigation event, one subplot was irrigated (moist treatment) while the other was not (dry treatment). Transpiration rates were determined at each subplot by the heat balance method (Dynamax Flow4 System) before, during and after the irrigations. During irrigations, there was a significant decrease in transpiration (60 \%) for the moist treatment. Within the first hour after irrigation, transpiration rates were also smaller for the moist treatment, but the reduction was lower (17\%). It was found a significant correlation between the transpiration reduction and the decrease of water vapor deficit during, and after the irrigation event. Leaf water potential during the irrigation increased (about $61 \%$ ) for the moist treatment, which suggests that the reduction of transpiration was not due to stomata closure but to smaller water vapor gradient between the plant and the surrounding atmosphere.
\end{abstract}

Keywords: Crop Microclimate, Irrigation Efficiency, Physiological Changes, Water Use, Zea mays L.

\section{INTRODUCTION}

The high evaporative demand during midday and early afternoon, typical of semiarid climates, reduces leaf water potential (LWP), regardless of soil water content, thus affecting stomata conductance and photosynthetic rates (Hirasawa and Hsiao, 1999). However, during daytime sprinkler irrigation, the crop microclimate is modified. Decreases of water vapor pressure deficit (VPD) and air temperature have been reported (Robinson, 1970; Steiner et al., 1983b; Tolk et al., 1995). The decrease in VPD would result in some reduction of the crop transpiration rates, leading to the conservation of soil water, which would otherwise be depleted by the crop (McNaughton, 1981; Steiner et al., 1983a). Due to this reduction of transpiration, some part of the application water losses during the irrigation event should not be considered as true losses. Consideration of net evaporation losses instead of gross evaporation losses would result in an increase of application efficiency for a given application depth (McNaughton, 1981; Tolk et al., 1995; Martínez-Cob et al., 2008). In addition to this beneficial effect of daytime sprinkler irrigation, the reduction in VPD would also result in a recovery of LWP during the irrigation events. 
Several studies have analyzed the differences in evapotranspiration and transpiration rates between wet and dry surfaces just after irrigation events, but not during the events themselves (McMillan and Burgy, 1960; Frost, 1963; Seginer, 1967; Waggoner et al., 1969). To our knowledge, very few works have measured evapotranspiration (Frost and Schwalen, 1960; Sternberg, 1967) or transpiration rates (Tolk et al., 1995) during sprinkler irrigation events. Tolk et al. (1995) reported a reduction of corn transpiration of about 36-41 \% during two daytime irrigation events using a lateral move sprinkler irrigation system in Texas (USA).

The aim of our work was to analyze the evolution of corn transpiration and LWP and quantify the corresponding changes during and just after sprinkler irrigation events using a solid-set system under typical operating factors in the study area in relation to sprinkler spacing, operating pressure and nozzle diameter.

\section{MATERIAL AND METHODS}

Experiments were conducted during 2005 and 2006 on a 2.0 ha field plot located in Montañana (Zaragoza, NE Spain). Mean annual precipitation, temperature and wind speed ( $2 \mathrm{~m}$ above ground) are $330 \mathrm{~mm}, 15{ }^{\circ} \mathrm{C}$ and $2.4 \mathrm{~m} \mathrm{~s}^{-1}$, respectively. The soil is classified as Typic Xerofluvent, sandy loam, mixed (calcareous), mesic. The experimental plot was divided in two subplots of 1.0 ha each (Figure 1). Corn (Zea mays L.) cv. Pioneer PR34N43 was sown on 26 April, both years. Agronomical practices (fertilization and application of herbicides and insecticides) were the same on both subplots. Emergence was 83,400 (2005) and 80,800 (2006) plants ha $^{-1}$ as determined by counting the plants at four sampling spots on each subplot at 19 (2005) and 26 (2006) days after sowing (DAS).

A solid-set sprinkler system (square spacing, $15 \mathrm{~m} \mathrm{x} 15 \mathrm{~m}$; sprinkler height, $2.2 \mathrm{~m}$; wetted diameter, about 15.1 to $15.3 \mathrm{~m}$ ) was installed at the experimental plot (Figure 1). Sprinklers had two nozzles with diameters of 4.4 and $2.4 \mathrm{~mm}$. Irrigation working pressure was measured every 5 min during each irrigation event with two transducers (model 2200/2600, Gems Basingstoke, Hampshire, UK) placed at one sprinkler of each subplot (Figure 1). In addition, each subplot was equipped with an automatic weather station to record 5-minute averages of air temperature and vapor pressure deficit before, during and after the daytime irrigation events.

Irrigations were scheduled to meet the crop water requirements, and computed weekly from reference evapotranspiration $\left(\mathrm{ET}_{\mathrm{o}}\right)$ estimates, obtained at a third automatic weather station located at an adjacent plot using the FAO Penman-Monteith method (Allen et al., 1998), using crop coefficients derived from relative cumulative degree-days (Martínez-Cob, 2008). Weekly crop water requirements were converted to weekly crop irrigation requirements $\left(\mathrm{IR}_{\mathrm{w}}\right)$ as described by Martínez-Cob et al. (2008).

Short and frequent irrigations were applied during the initial crop stages (May) to favor crop establishment. Later, the weekly crop irrigation requirements were applied in three (rarely two) weekly irrigation events for each subplot, lasting around a maximum of $3 \mathrm{~h}$. The applied irrigation water depth in each irrigation event was the same at each subplot, but irrigations were not simultaneous. Generally, subplot A was irrigated on daytime periods (starting between 12:00 and 14:30 Greenwich Mean Time, GMT) at the beginning and the weekend, while subplot B was irrigated on night time periods the 
following day. At the middle of the week, subplot A was irrigated on night time periods and subplot B on daytime periods the same day. Thus, two irrigation treatments were considered at each daytime irrigation event: a) moist treatment (MT), the subplot being irrigated; and b) dry treatment (DT), the other subplot (Table 1).

A sap flow measurement system (Dynamax, Houston, Texas, USA) was installed in each subplot on 13 July (78 DAS) in 2005 and 30 June (65 DAS) in 2006 (Figure 1). Each system had a data logger and four sap gauges (SGB19), appropriate for stems of 18$23 \mathrm{~mm}$ in diameter, installed at four representative corn plants following Van Bavel (2005). The heat balance method was applied to obtain corn transpiration rates for each plant every 15 (in 2005) or 20 minutes (in 2006) (Baker and Van Bavel, 1987; Weibel and Boersma, 1995; Van Bavel, 2005) and converted into $\mathrm{mm} \mathrm{h}^{-1}$ considering the measured average plant densities. Data was downloaded to a PC using a mobile communication system based on Global System for Mobile (GSM) modems. This system allowed a call to be made from the office and, once the connection has been established with the modem located in the cornfield, which is connected with the logger by the serial port, the recorded data was downloaded using the Dynamax software. Average transpiration values were obtained for the whole duration of each irrigation event and for $1 \mathrm{~h}$ periods during the $2 \mathrm{~h}$ before the start and the $3 \mathrm{~h}$ after the end of each irrigation event.

The LWP of corn plants was measured with a Scholander pressure chamber (model 3115, Portable Water Status) during three irrigation events (13, 24 and 31 July 2006). Before the irrigation started and after it finished, LWP was measured every 15 minutes. During the irrigation event, LWP was measured every 30 minutes. At each measurement period two plants were randomly selected, the ear insertion leaves were cut and the LWP was measured immediately. For each measurement period, the LWP of the two sampled plants were averaged.

\section{RESULTS AND DISCUSSION}

The seasonal applied irrigation water amounted $736 \mathrm{~mm}$ (in 2005) and $688 \mathrm{~mm}$ (in 2006) for subplot A, and 778 (in 2005) and $708 \mathrm{~mm}$ (in 2006) for subplot B. On average, for the periods during which the daytime irrigation events were applied, the weather of 2006 was warmer with higher solar radiation and estimated $\mathrm{ET}_{0}$, but less windy and with lower vapor pressure deficit compared to 2005 (Martínez-Cob et al., 2008). There were 23 daytime irrigation events for which transpiration rates were measured. Subplot A was the $M T$ for 15 of those events. Averages of irrigation pressure, water application rate and irrigation duration were $381 \mathrm{kPa}(\mathrm{CV}=3.7 \%), 8.4 \mathrm{~mm} \mathrm{~h}^{-1}(\mathrm{CV}=1.8 \%)$, and $2.5 \mathrm{~h}$ $(\mathrm{CV}=13.4 \%)$, respectively, in 2005. Those figures were $302 \mathrm{kPa}(\mathrm{CV}=4.5 \%), 7.5 \mathrm{~mm} \mathrm{~h}^{-1}$ (CV=2.1\%), and $2.9 \mathrm{~h}(\mathrm{CV}=9.4 \%)$, respectively, in 2006.

Figure 2 shows the corn transpiration rate from $2 \mathrm{~h}$ before until $3 \mathrm{~h}$ after two different irrigation events. These results are representative of those observed for the rest of irrigation events. Transpiration rates before irrigation were similar in both treatments. As soon as irrigation started, the transpiration rate of the $M T$ sharply decreased and this lower transpiration rate continued up to the end of the irrigation event. Once the irrigation event finished, the transpiration rate of the $M T$ progressively increased until matching that of the DT. In $65 \%$ of the irrigation events the matching occurred in the following hour to the end of irrigation. Only in $5 \%$ of the irrigation events the matching of transpiration 
rates was delayed until $2 \mathrm{~h}$ after the end of the irrigation. Tolk et al. (1995) reported negligible changes of corn transpiration rates during two irrigation events under a low energy precision application (LEPA) irrigation system, but a high reduction of transpiration rates during other two irrigation events under a lateral move (impact sprinklers) irrigation system. For these latter irrigation events, Tolk et al. (1995) reported a longer duration of the recovery time of transpiration rates than observed in this study. This difference could be due to the differences in the irrigated area and in the irrigation system between both research works.

Figure 3 shows the average corn transpiration rate before (1-2 h), during, and after (1-3 h) each daytime sprinkler irrigation event for the MT and the DT. There were not significant differences $(p=0.05)$ between treatments before irrigation started. However, during the irrigation event itself, transpiration rates at the $M T$ were significantly ( $\mathrm{p}=$ 0.05 ) lower, about $60 \%$, than those at the DT. After the irrigation finished, there were significant differences $(\mathrm{p}=0.05)$ between both treatments only during the first hour (Figure 3), being the transpiration rates at the MT about $17 \%$ lower. This transpiration reduction during and after sprinkler irrigation was similar to that reported by Tolk et al. (1995) after analyzing two daytime corn irrigation events in Texas using a lateral move sprinkler irrigation system. Both sources of experimental data show that transpiration is highly but not completely reduced during irrigation. This complete reduction of transpiration was predicted by simulation models such as that of Thompson et al. (1993).

The evolution of vapor pressure deficit (VPD) before, during and after the irrigation events was similar to that of transpiration rates (Figure 2). Due to the reduction of VPD caused by the evaporation of water from the droplets in their way from the sprinkler nozzles to the soil, the evaporative demand decreased and consequently the transpiration rate also decreased. The LWP at the $M T$ increased during and just after the irrigations (Figure 2). In average, the LWP of maize in the MT was $61 \%$ higher than that of the DT during the irrigation event (Table 2). One hour after the irrigation event the LWP of maize in the MT was $20 \%$ higher. In this experiment, irrigations were scheduled to meet crop water requirements at both subplots and therefore to keep crop water status at an optimum value. Nevertheless, in semiarid climates, the evaporative demand during midday is so high that LWP decreases because of partial stomata closure, even though there is adequate soil moisture (Hirasawa and Hsiao, 1999). The increase of LWP during, and after the sprinkler irrigation, found in this study, indicates that sprinkler irrigation could relieve the crop of that mild stress.

During sprinkler irrigation, some water is lost due to wind drift and evaporation (WDEL) as water travels from the sprinkler nozzles to the crop, as well as to evaporation that occurs from water intercepted by stems and leaves after the irrigation event (Tolk et al., 1995). These losses modify the microclimatic conditions wherein the crop grows and results in plant physiological changes.

The observed reduction of transpiration should be subtracted from the gross WDEL, as these losses partially contribute to crop water requirements. Thus, net WDEL rather than gross WDEL should be taken into account when evaluating water application efficiency of a sprinkler irrigation system (McNaughton, 1981; Tolk et al., 1995) although the differences between gross and net losses may be relatively low for irrigation events lasting only few hours (Martínez-Cob et al., 2008). 
The observed increase in LWP caused by daytime sprinkler irrigation indicates a better water status of the plants and suggests that the reduction of transpiration was not due to stomata closure, but to the smaller water vapor gradient between the plant and the surrounding atmosphere.

\section{CONCLUSIONS}

Sprinkler irrigation with a solid-set system during daytime decreased corn transpiration rate by $60 \%$ during the irrigation event and by $17 \%$ during the hour following after the irrigation event finished. This reduction of transpiration was due to the reduction of VPD and therefore the lower evaporative demand during the irrigation events. In addition, the LWP of corn plants increased by $61 \%$ during the irrigation events and by $20 \%$ during the following hour after the irrigation event finished. Whether the change in LWP would result in increased plant production should be further studied.

\section{ACKNOWLEDGEMENTS}

This work was supported by grant AGL-2004-06675-CO3-02 (PN I+D+I, Ministerio de Educación y Ciencia of Spain). Thanks are due to M. Izquierdo, J. Gaudó, D. Mayoral, J.M. Acín and P. Paniagua for field assistance and to S. Gonuguntla (Dynamax Inc.) for technical assistance in sap flow measurement implementation.

\section{Literature Cited}

Allen, R.G., Pereira, L.S., Raes, D. and Smith, M. 1998. Crop evapotranspiration: guidelines for computing crop water requirements. FAO Irrigation and Drainage Paper 56. FAO, Rome, Italy.

Baker, J.M. and Van Bavel, C.H.M. 1987. Measurement of mass flow of water in the stems of herbaceous plants. Plant Cell Environ. 10: 777-782.

Frost, K.R. 1963. Factors affecting evapotranspiration losses during sprinkling. Trans. ASAE. 6: 282-283, 287.

Frost, K.R. and Schwalen, H.C. 1960. Evapotranspiration during sprinkler irrigation. Trans. ASAE. 3: 18-20, 24.

Hirasawa, T. and Hsiao, T.C. 1999. Some characteristics of reduced leaf photosynthesis at midday in maize growing in the field. Field Crops Research. 62: 53-62.

Martínez-Cob, A. 2008. Use of thermal units to estimate corn crop coefficients under semiarid climatic conditions. Irrig. Sci. 26: 335-345.

Martínez-Cob, A., Playán, E., Zapata, N., Cavero, J., Medina, E.T. and Puig M. 2008. Contribution of evapotranspiration reduction during sprinkler irrigation to application efficiency. J. Irrig. Drain. Engr. 134 (6): 745-756.

McMillan, W.D. and Burgy, R.H. 1960. Interception loss from grass. J. Geophys. Res. 65: 2389-2394. 
McNaughton, K.G. 1981. Net interception losses during sprinkler irrigation. Agric. Meteorol. 24: 11-27.

Robinson, F.E. 1970. Modifying an arid microclimate with sprinklers. Agric. Engr. 51: 465.

Seginer, I. 1967. Net losses in sprinkler irrigation. Agric. Meteorol. 4: 281-291.

Steiner, J.L., Kanemasu, E.T. and Clark, R.N. 1983a. Spray losses and partitioning of water under a center pivot sprinkler system. Trans. ASAE. 26: 1128-1134.

Steiner, J.L., Kanemasu, E.T. and Hasza, D. 1983b. Microclimatic and crop responses to center pivot sprinkler and to surface irrigation. Irrig. Sci. 4: 201-214.

Sternberg, Y.M. 1967. Analysis of sprinkler irrigation losses. J. Irrig. Drain. Div., Proc. Am. Soc. Civil Engrs. 93 (IR4): 111-124.

Thompson, A.L., Gilley, J.R. and Norman, J.M. 1993. A sprinkler water droplet evaporation and plant canopy model: II. Model application. Trans. ASAE. 36: 743750.

Tolk, J.A, Howell, T.A., Steiner, J.L., Krieg, D.R. and Schneider, A.D. 1995. Role of transpiration suppression by evaporation of intercepted water in improving irrigation efficiency. Irrig. Sci. 16: 89-95.

Van Bavel, M.G. 2005. Flow4 Installation and Operation Manual. Dynamax Inc., Houston, Texas.

Waggoner, P.E., Begg, J.E. and Turner, N.C. 1969. Evaporation of dew. Agric. Meteorol. 6: $227-230$.

Weibel, F.P. and Boersma, K. 1995. An improved stem heat balance method using analog heat control. Agric. For. Meteorol. 75: 191-208. 


\section{TABLES}

Table 1. General scheme of weekly daytime irrigation events.

\begin{tabular}{|c|c|c|}
\hline Period & Moist treatment (MT) & Dry treatment (DT) \\
\hline Beginning of the week & Subplot A & Subplot B \\
Middle of the week & Subplot B & Subplot A \\
Weekend & Subplot A & Subplot B \\
\hline
\end{tabular}

Table 2. Average leaf water potential of the moist ( $\overline{\mathrm{LWP}_{\mathrm{MT}}}$ ) and the dry $\left(\overline{\mathrm{LWP}_{\mathrm{DT}}}\right)$ treatments $1 \mathrm{~h}$ before, during and 1-3 h after three irrigation events, as well as the average differences between them $\left(\overline{\mathrm{LWP}_{\mathrm{DT}}}-\overline{\mathrm{LWP}_{\mathrm{MT}}}\right)$. N, sample size.

\begin{tabular}{|l|c|c|c|c|}
\hline \multicolumn{1}{|c|}{ Period } & $\mathrm{N}$ & $\overline{\mathrm{LWP}_{\mathrm{MT}}}(\mathrm{MPa})$ & $\overline{\mathrm{LWP}_{\mathrm{DT}}}(\mathrm{MPa})$ & $\overline{\mathrm{LWP}_{\mathrm{DT}}}-\overline{\mathrm{LWP}_{\mathrm{MT}}}(\mathrm{MPa})$ \\
\hline 1 h before & 19 & -1.57 & -1.48 & $0.09^{*}$ \\
During & 23 & -0.57 & -1.45 & $-0.88^{*}$ \\
1 h after & 14 & -0.99 & -1.22 & $-0.24^{*}$ \\
2-3 h after & 5 & -1.06 & -1.22 & $-0.16^{*}$ \\
\hline
\end{tabular}

* significantly different (paired t-test). 


\section{FIGURES}

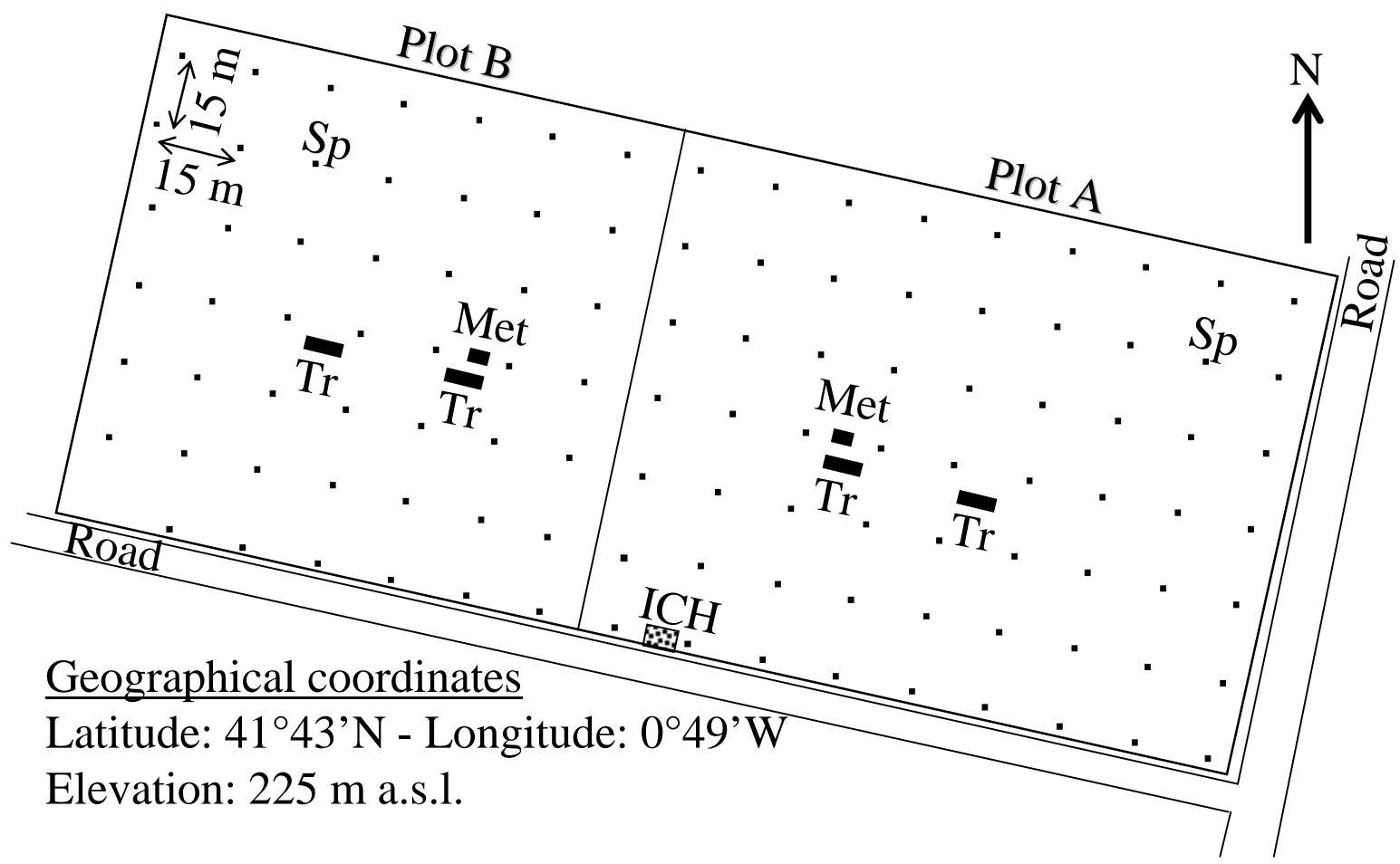

Figure 1. Scheme of the experimental plot. Tr, sap flow gages; Met, automatic meteorological stations; Sp, sprinklers; ICH, irrigation control hut. 

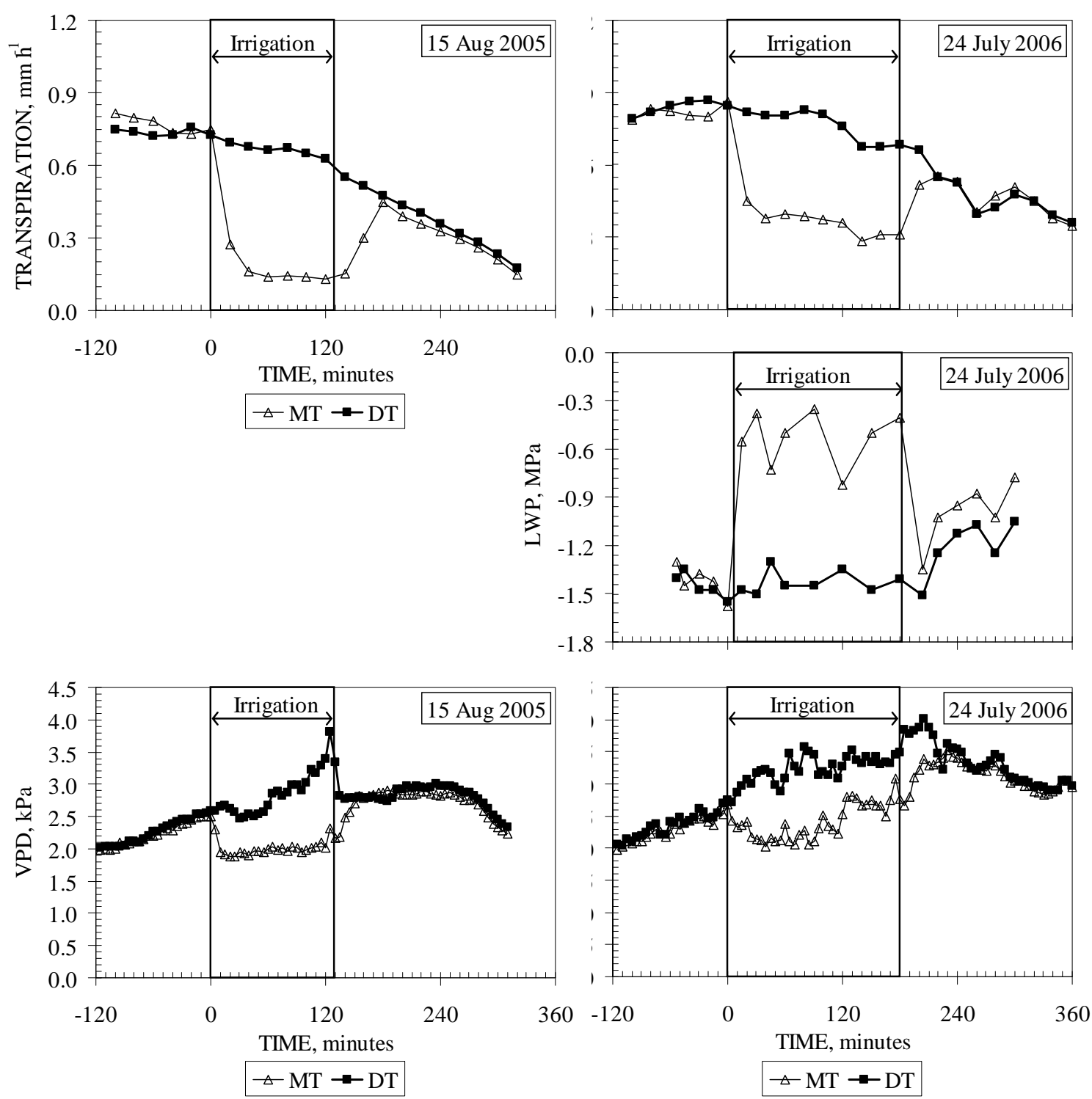

Figure 2. Evolution of corn transpiration rate, leaf water potential (LWP) and vapor pressure deficit (VPD) from $2 \mathrm{~h}$ before until $3 \mathrm{~h}$ after two daytime irrigation events. MT, moist treatment; DT, dry treatment. 

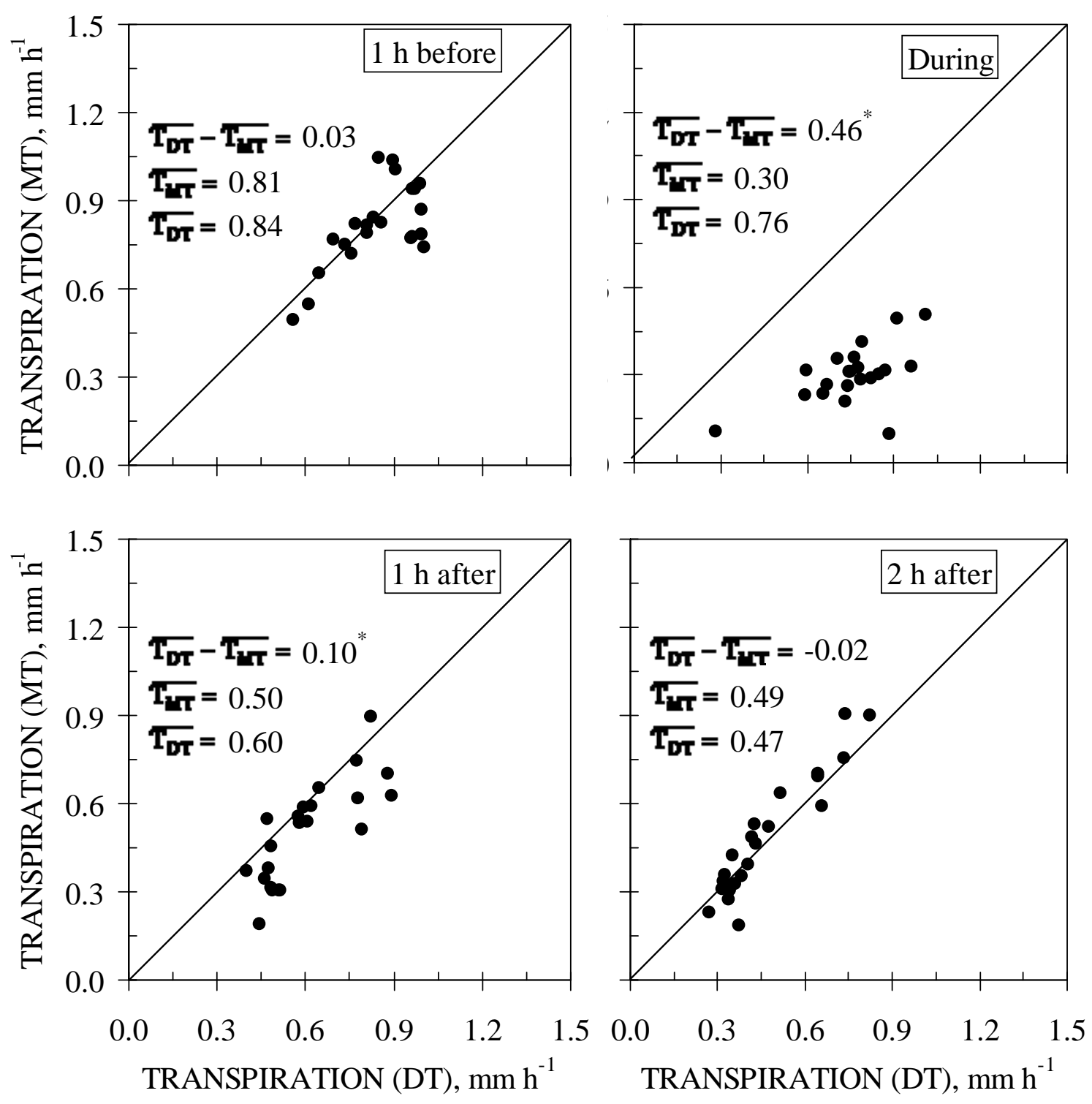

Figure 3. Average corn transpiration rate $1 \mathrm{~h}$ before, during, and 1-2 $\mathrm{h}$ after daytime sprinkler irrigation events at the moist treatment (MT) versus the corresponding rates recorded at the dry treatment (DT). $\overline{\mathrm{T}_{\mathrm{MT}}}$ and $\overline{\mathrm{T}_{\mathrm{DT}}}$, averages of all irrigation events at the MT and the DT, respectively. * significantly different (paired t-test). 